\title{
Enhanced visible-light photo-oxidation of nitric oxide using bismuth-coupled graphitic carbon nitride composite heterostructures
}

\author{
Yuhan Li a , Kangle Lv ${ }^{\text {a,c,*, Wingkei Ho }}{ }^{\text {a,b,\#, Zaiwang Zhao a , Yu Huang }}{ }^{\text {b }}$ \\ a Department of Science and Environmental Studies, The Education University of Hong Kong, Tai Po, N.T., Hong Kong, China \\ b Key Laboratory of Aerosol Chemistry and Physics, Institute of Earth Environment, Chinese Academy of Sciences, Xi'an 710061, Shanxi, China \\ ${ }^{c}$ Key Laboratory of Catalysis and Materials Science of the State Ethnic Affairs Commission and Ministry of Education, College of Resources and Environ- \\ mental Science, South-Central University for Nationalities, Wuhan 430074, Hubei, China
}

\section{A R T I C L E I N F}

\section{Article history:}

Received 29 August 2016

Accepted 5 October 2016

Published 5 February 2017

\section{Keywords:}

Bismuth

Surface plasmon resonance

Photo-oxidation

Nitric oxide

Visible light

Graphitic carbon nitride

\begin{abstract}
A B S T R A C T
Pure bismuth (Bi) metal-modified graphitic carbon nitride $\left(\mathrm{g}-\mathrm{C}_{3} \mathrm{~N}_{4}\right)$ composites (Bi-CN) with a pomegranate-like structure were prepared by an in situ method. The Bi-CN composites were used as photocatalysts for the oxidation of nitric oxide (NO) under visible-light irradiation. The inclusion of pure Bi metal in the g- $\mathrm{C}_{3} \mathrm{~N}_{4}$ layers markedly improved the light absorption of the Bi-CN composites from the ultraviolet to the near-infrared region because of the typical surface plasmon resonance of Bi metal. The separation and transfer of photogenerated charge carriers were greatly accelerated by the presence of built-in Mott-Schottky effects at the interface between Bi metal and g- $\mathrm{C}_{3} \mathrm{~N}_{4}$. As a result, the Bi-CN composite photocatalysts exhibited considerably enhanced efficiency in the photocatalytic removal of $\mathrm{NO}$ compared with that of Bi metal or g- $\mathrm{C}_{3} \mathrm{~N}_{4}$ alone. The pomegranate-like structure of the Bi-CN composites and an explanation for their improved photocatalytic activity were proposed. This work not only provides a design for highly efficient g- $\mathrm{C}_{3} \mathrm{~N}_{4}$-based photocatalysts through modification with $\mathrm{Bi}$ metal, but also offers new insights into the mechanistic understanding of $\mathrm{g}-\mathrm{C}_{3} \mathrm{~N}_{4}$-based photocatalysis.
\end{abstract}

(C) 2016, Dalian Institute of Chemical Physics, Chinese Academy of Sciences. Published by Elsevier B.V. All rights reserved.

\section{Introduction}

The potential for noble metal-based materials to harvest and convert solar energy has garnered considerable attention in recent years [1-3]. In particular, the ability of noble metals to strongly absorb visible light because of their localized surface plasmon resonance (SPR), which considerably increases their utilization efficiency of visible light, is important for their application $[4,5]$. In view of expense of precious metals, some affordable and readily available metals possessing similar electronic and light-absorption characteristics to those of noble metals have been investigated as substitutes [6-10]. It is well documented that the semimetal bismuth (Bi) behaves as a photocatalyst with promising photocatalytic performance [10].

\footnotetext{
* Corresponding author. Tel: +86-27-67841369; Fax: +86-27-67843918; E-mail: lvkangle@mail.scuec.edu.cn

\# Corresponding author. Tel: +852-29488255; Fax: +852-29487726; E-mail: keithho@eduhk.hk

This work was supported by the National Program on Key Basic Research Project (2016YFA0203000), the Early Career Scheme (ECS 809813) from the Research Grant Council, Hong Kong SAR Government, the Croucher Foundation Visitorship for PRC Scholars 2015/16 at The Education University of Hong Kong, the National Natural Science Foundation of China (51672312, 21373275), and the Program for New Century Excellent Talents in University (NCET-12-0668).

DOI: 10.1016/S1872-2067(16)62573-1| http://www.sciencedirect.com/science/journal/18722067 | Chin. J. Catal., Vol. 38, No. 2, February 2017
} 
Pure Bi metal can exhibit admirable photocatalytic reactivity under ultraviolet (UV) irradiation $(\lambda \leq 280 \mathrm{~nm})$, but its response to visible light is poor [11]. Thus, it is important to develop feasible and environmentally benign strategies to afford Bi with visible-light activity.

Graphitic carbon nitride $\left(\mathrm{g}-\mathrm{C}_{3} \mathrm{~N}_{4}\right)$ can photocatalytically break down various pollutants into harmless chemicals and photocatalyze water conversion to hydrogen and hydrogen peroxide under visible-light irradiation [12-15]. However, the photocatalytic efficiency of bulk g- $\mathrm{C}_{3} \mathrm{~N}_{4}$ is quite low because of its marginal absorption of visible light and poor separation of photogenerated carriers; therefore, effective modification methods need to be developed to improve its visible-light performance. For this reason, a number of g- $\mathrm{C}_{3} \mathrm{~N}_{4}$-based heterostructures with synergetic coupling effects between g- $\mathrm{C}_{3} \mathrm{~N}_{4}$ and other functional materials have been developed to greatly enhance its absorption of visible light and facilitate charge transfer [16-18]. Recently, Dong et al. [19] synthesized Bi nanosphere-modified g- $\mathrm{C}_{3} \mathrm{~N}_{4}$ nanosheets $\left(\mathrm{Bi}-\mathrm{g}-\mathrm{C}_{3} \mathrm{~N}_{4}\right)$ with excellent photocatalytic performance. The as-obtained Bi-g- $\mathrm{C}_{3} \mathrm{~N}_{4}$ composites combined with some bismuth oxide $\left(\mathrm{Bi}_{2} \mathrm{O}_{3}\right)$ layers offered two major advantages over pure g- $\mathrm{C}_{3} \mathrm{~N}_{4}$ in photocatalytic reactions. On one hand, by loading Bi metal on the surface of $\mathrm{g}-\mathrm{C}_{3} \mathrm{~N}_{4}$, Bi-coupled g- $\mathrm{C}_{3} \mathrm{~N}_{4}$ nanocomposites with a strong visible-light response were obtained because of the SPR effects of Bi. On the other hand, the supporting Bi nanospheres accelerated the separation of photogenerated charge carriers because of the formation of a Mott-Schottky barrier at the Bi/g- $\mathrm{C}_{3} \mathrm{~N}_{4}$ interface. However, $\mathrm{Bi}_{2} \mathrm{O}_{3}$ formed on the surface of $\mathrm{Bi}-\mathrm{g}-\mathrm{C}_{3} \mathrm{~N}_{4}$ composites can have a shielding effect that deteriorates the above-mentioned contributions from $\mathrm{Bi}$. Dong and colleagues [19] used bismuth nitrate pentahydrate $\left(\mathrm{Bi}\left(\mathrm{NO}_{3}\right)_{3} \cdot 5 \mathrm{H}_{2} \mathrm{O}\right)$ as the precursor for Bi metal, but the oxidizing ability endowed by $\mathrm{NO}_{3}-$ led to the generation of $\mathrm{Bi}_{2} \mathrm{O}_{3}$ in the resultant composites. Along this line of thinking, it is necessary to prepare pure $\mathrm{Bi}$ metal-coupled $\mathrm{g}-\mathrm{C}_{3} \mathrm{~N}_{4}$ composites without $\mathrm{Bi}_{2} \mathrm{O}_{3}$ layers by using a substitute for $\mathrm{Bi}\left(\mathrm{NO}_{3}\right)_{3} \cdot 5 \mathrm{H}_{2} \mathrm{O}$.

Nitric oxide (NO) and nitrogen dioxide $\left(\mathrm{NO}_{2}\right)$, jointly referred to as $\mathrm{NO}_{x}$, are typical indoor and outdoor air pollutants that are causing increasing environmental concern. $\mathrm{NO}_{x}$ is one of the major contributors to acid rain and urban smog, and could result in serious respiratory diseases, hospitalization for heart or lung diseases, and even premature death [19].

In the present study, pure Bi metal-modified g- $\mathrm{C}_{3} \mathrm{~N}_{4}(\mathrm{Bi}-\mathrm{CN})$ composites are fabricated by an in situ grafting treatment. These composites show high reactivity in photo-oxidation of NO under visible-light illumination. Sodium bismuthate $\left(\mathrm{NaBiO}_{3} \cdot 2 \mathrm{H}_{2} \mathrm{O}\right)$ is successfully used as a precursor of Bi metal to obtain pure Bi metal in the Bi-CN composites. The composites are investigated by X-ray diffraction (XRD), Fourier transform infrared (FT-IR) spectroscopy, and X-ray photoelectron spectroscopy (XPS). The photo-oxidation of NO by the Bi-CN composites is evaluated.

\section{Experimental}

\subsection{Preparation of Bi-CN composites}

All chemicals were of analytical grade and used without further purification. We synthesized $\mathrm{g}-\mathrm{C}_{3} \mathrm{~N}_{4}$ by heating dicyanamide $(20 \mathrm{~g})$ at $550{ }^{\circ} \mathrm{C}$ for $2 \mathrm{~h}$. To synthesize the Bi-CN composite photocatalysts, $\mathrm{NaBiO}_{3} \cdot 2 \mathrm{H}_{2} \mathrm{O}(0.339 \mathrm{~g})$ was completely dissolved in ethylene glycol (EG, $30 \mathrm{~mL}$ ) under continuous magnetic stirring and then polyvinylpyrrolidone (PVP, MW $130,000,0.2 \mathrm{~g}$ ) was added. The molar ratio of Bi to the repeating unit of PVP was controlled at 1:1.6. A certain amount of g- $\mathrm{C}_{3} \mathrm{~N}_{4}$ was then added to the solution under vigorous stirring. After stirring for $1 \mathrm{~h}$, the mixture was transferred into a 100-mL Teflon-sealed autoclave, sealed and heated at $200{ }^{\circ} \mathrm{C}$ for $24 \mathrm{~h}$ in a furnace, before cooling to room temperature. The product was centrifuged, and then washed with acetone followed by ethanol several times to remove residual EG and PVP. $\mathrm{Bi}$-CN photocatalysts with different weight ratios of metallic $\mathrm{Bi}$ to $\mathrm{CN}$ (namely, 5\% Bi-CN, 10\% Bi-CN, 15\% Bi-CN, 25\% Bi-CN, and $50 \% \mathrm{Bi}-\mathrm{CN}$ ) were synthesized. Metallic $\mathrm{Bi}$ and solvothermally prepared g- $\mathrm{C}_{3} \mathrm{~N}_{4}$ (CN-EG) were also prepared as reference samples, using the same procedure as that for the Bi-CN composites except that only either $\mathrm{g}-\mathrm{C}_{3} \mathrm{~N}_{4}$ or $\mathrm{Bi}$ was added.

\subsection{Characterization}

The phase structures of the samples were investigated by XRD (D/max RA, Japan). The morphological characteristics and microstructures of the samples were characterized with a scanning electron microscope (SEM; JEOL JSM-6490, Japan). Nitrogen adsorption-desorption isotherms were obtained using a nitrogen adsorption apparatus (ASAP 2020, USA), in which all of the samples were degassed at $150{ }^{\circ} \mathrm{C}$ prior to the measurements to investigate their surface areas and pore size distributions. Samples embedded in $\mathrm{KBr}$ pellets were subjected to FT-IR spectroscopy in a Nicolet Nexus spectrometer to detect the functional groups on their surfaces. The surface chemical composition and total density of state distribution in the valence band (VB) of each sample were probed using an X-ray photoelectron spectrometer (Thermo ESCALAB 250, USA) with Al $K_{\alpha}$ X-rays $(h v=1486.6 \mathrm{eV})$ operated at $150 \mathrm{~W}$. The shift of the binding energy attributed to relative surface charging was corrected using the $\mathrm{C} 1 \mathrm{~s}$ level at $284.8 \mathrm{eV}$ as an internal standard. The optical properties of the samples were measured by an ultraviolet-visible diffuse reflectance spectrophotometer (UV-Vis DRS; UV-2450, Shimadzu, Japan) equipped with an integrating sphere assembly; $\mathrm{BaSO}_{4}$ was used as the reflectance sample. Photoluminescence (PL) spectra of the samples were obtained with a fluorescence spectrophotometer (FS-2500, Japan) using a Xe lamp with an optical filter as the excitation source to investigate the recombination and separation of photogenerated electrons and holes.

\subsection{Visible-light photocatalytic activity.}

The photocatalytic activity of the samples was evaluated through the oxidation of NO at the $10^{-6}$ level in a continuous-flow reactor at ambient temperature. The volume of the rectangular reactor composed of stainless steel and covered with quartz glass was $4.5 \mathrm{~L}(30 \times 15 \times 10 \mathrm{~cm})$. An LED lamp 
(448 nm) was used as a simulated visible-light source. Photocatalyst $(0.2 \mathrm{~g})$ was added to $\mathrm{H}_{2} \mathrm{O}(30 \mathrm{~mL})$ and ultrasonicated for $30 \mathrm{~min}$. The resulting suspension was coated onto a dish with a diameter of $11.5 \mathrm{~cm}$. The coated dish was pretreated at $70{ }^{\circ} \mathrm{C}$ to evaporate water thoroughly and then cooled to room temperature prior to photocatalytic testing. NO gas was introduced from a compressed gas cylinder containing $50 \times 10^{-6} \mathrm{NO}$ (balance $\mathrm{N}_{2}$ ) in accordance with the traceable standard recommended by the National Institute of Standards and Technology. The initial NO concentration was diluted to approximately $600 \times 10^{-9}$ by an air stream supplied by a zero-air generator (Advanced Pollution Instrumentation, Teledyne Technologies, Model 701). The gas streams were completely premixed in a gas blender, and the flow rate was controlled at $1.0 \mathrm{~L} \cdot \mathrm{min}^{-1}$ with a mass flow controller. After adsorption-desorption equilibrium was achieved, the lamp was turned on. The $\mathrm{NO}$ and $\mathrm{NO}_{2}$ concentrations were continuously measured using a chemiluminescence $\mathrm{NO}_{x}$ analyzer (Advanced Pollution Instrumentation, Teledyne Technologies, Model T200) that monitored $\mathrm{NO}, \mathrm{NO}_{2}$, and $\mathrm{NO}_{x}\left(\mathrm{NO}_{x}\right.$ represents $\left.\mathrm{NO}+\mathrm{NO}_{2}\right)$ at a sampling rate of $1.0 \mathrm{~L} \cdot \mathrm{min}^{-1}$. The removal ratio of $\mathrm{NO}(\eta)$ was calculated as $\eta(\%)=\left(1-C / C_{0}\right) \times 100 \%$, where $C$ and $C_{0}$ are the NO concentration in the outlet steam and feed stream, respectively.

\section{Results and discussion}

\subsection{Photocatalytic removal of NO}

The variations of $\mathrm{NO}$ removal rate and $\mathrm{NO}_{2}$ concentration with visible-light irradiation time in the presence of different samples are shown in Fig. 1. Control experiments in the absence of either photocatalyst or light irradiation were also performed, which demonstrated that the presence of both photocatalyst and visible light was required for removal of $\mathrm{NO}$ to occur. Fig. 1(a) clearly shows that g- $\mathrm{C}_{3} \mathrm{~N}_{4}$ alone possessed feeble NO photo-oxidation capability, much lower than that of the solvothermally prepared CN-EG, which showed a reasonable $\eta$ in NO oxidation of approximately $37 \%$. This result showed that

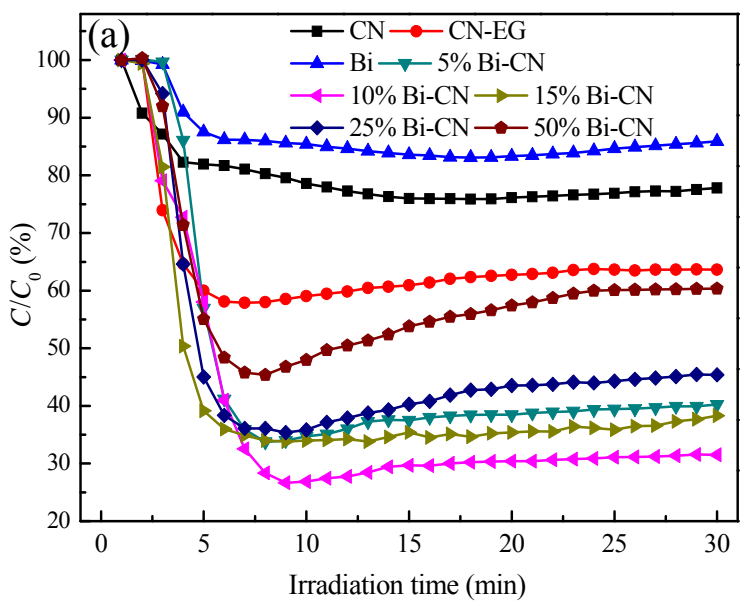

EG-assisted solvothermal treatment contributed to the increase of photocatalytic activity of $\mathrm{g}-\mathrm{C}_{3} \mathrm{~N}_{4}$ in NO oxidation, as reported in the literature, because of the positive directing effect of EG on the morphology of $\mathrm{g}-\mathrm{C}_{3} \mathrm{~N}_{4}$ [20]. In this context, to afford markedly enhanced visible-light activity, various contents of elemental Bi were introduced into the g- $\mathrm{C}_{3} \mathrm{~N}_{4}$-based photocatalyst system. Under visible-light illumination, metallic $\mathrm{Bi}$ showed little photocatalytic oxidation NO activity, likely because $\mathrm{Bi}$ alone requires UV irradiation to catalyze NO photo-oxidation [11]. In contrast, the Bi-CN composites displayed much improved photocatalytic oxidation abilities in this process. That these Bi-CN composites exhibited marked enhancement of photocatalytic activity in photo-oxidation of NO compared with both $\mathrm{g}-\mathrm{C}_{3} \mathrm{~N}_{4}$ and $\mathrm{Bi}$ alone was anticipated. This is because introduction of elemental $\mathrm{Bi}$ commonly results in considerable photo-oxidation activity towards NO, which can mainly be attributed to the synergistic effects of improved charge separation and SPR endowed by Bi metal upon irradiation with visible light ( $\lambda>448 \mathrm{~nm}$ ) [19]. Nevertheless, Fig. 1(a) reveals that the photo-oxidation reactivities of the $\mathrm{Bi}-\mathrm{CN}$ composites for NO decreased with increasing Bi metal content beyond the optimum composition of $10 \%$ Bi-CN. Excess Bi metal $(>10 \%)$ in the Bi-CN composites resulted in a negative influence on the photo-oxidation performance, which could be explained as follows: (1) a large amount of Bi metal on the surface of the Bi-CN composite may physically block g- $\mathrm{C}_{3} \mathrm{~N}_{4}$ from absorbing visible light to the detriment of visible-light-harvesting ability; (2) a substantial content of Bi metal in the Bi-CN composites may strongly absorb UV light $(\lambda<280 \mathrm{~nm})$ rather than visible light, thus deteriorating the visible-light-driven photocatalytic oxidation efficiency of the catalyst towards NO.

Fig. 1(a) also shows that several of the photocatalytic oxidation profiles first decreased and then increased with irradiation time. This is because some of the oxidation intermediates and/or products formed during $\mathrm{NO}$ oxidation, such as $\mathrm{NO}_{3}^{-}$, were adsorbed on the photocatalyst surface, decreasing the number of active sites and slowing NO degradation [23].

More importantly, as shown in Fig. 1, $\eta$ (70.4\%) and the $\mathrm{NO}_{2}$ concentration (less than $10 \times 10^{-9}$ ) of $10 \%$ Bi-CN are much

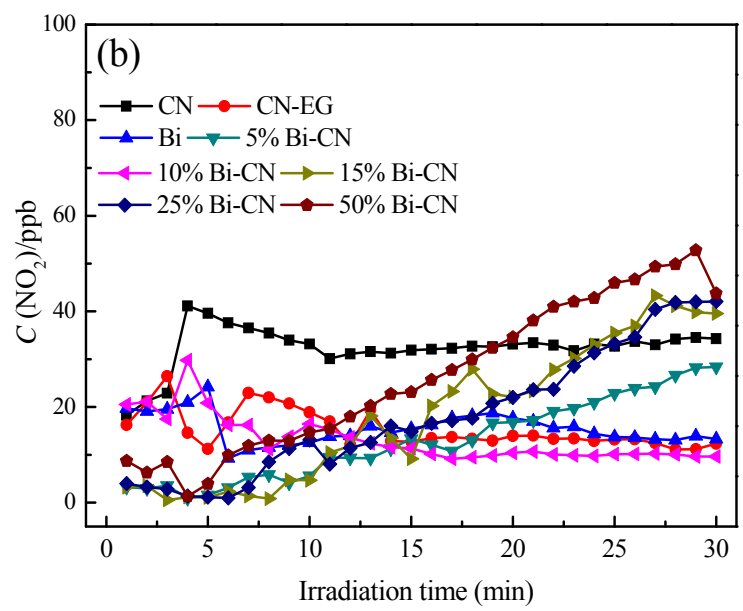

Fig. 1. Photocatalytic removal of $\mathrm{NO}$ (a) and monitoring concentration of $\mathrm{NO}_{2}$ intermediates in a single-pass flow of air over the as-obtained samples under visible-light irradiation (b) (continuous reactor; initial NO concentration: $600 \times 10^{-9}$ ). 
Table 1

Physical properties and removal rate of NO for photocatalysts and reference samples.

\begin{tabular}{lccccc}
\hline Sample & $\begin{array}{c}A_{\mathrm{BET}} \\
\left(\mathrm{m}^{2} \cdot \mathrm{g}^{-1}\right)\end{array}$ & $\begin{array}{c}V_{\text {pore }} \\
\left(\mathrm{cm}^{3} \cdot \mathrm{g}^{-1}\right)\end{array}$ & $\begin{array}{c}\text { Peak pore } \\
\text { size }(\mathrm{nm})\end{array}$ & $\begin{array}{c}\eta^{a} \\
(\%)\end{array}$ & Ref. \\
\hline $\mathrm{CN}$ & 9 & 0.055 & $1.8 / 16.4$ & 22.2 & this work \\
$\mathrm{CN}-\mathrm{EG}$ & 53 & 0.18 & $1.8 / 4.8$ & 36.4 & this work \\
$\mathrm{Bi}$ & 3 & 0.026 & 15.5 & 14.1 & this work \\
$10 \% \mathrm{Bi}-\mathrm{CN}$ & 42 & 0.17 & $1.9 / 6.8$ & 70.4 & this work \\
$15 \% \mathrm{Bi}-\mathrm{CN}$ & 42 & 0.18 & $1.8 / 11.6$ & 61.7 & this work \\
$\mathrm{CN}-\mathrm{GO}$ & - & - & - & 60.7 & {$[21]^{\mathrm{b}}$} \\
K-intercalated & - & - & - & 36.8 & {$[22]^{\mathrm{c}}$} \\
g-C $\mathrm{N}_{4}$ & - & - & - & 54.3 & {$[23]^{\mathrm{d}}$} \\
Ag-doped g-C $\mathrm{N}_{4}$ & & - & - & 60.2 & {$[19]^{\mathrm{e}}$} \\
Bi-CN-25 & & & & & \\
\hline
\end{tabular}

a NO removal ratio.

${ }^{b}$ Weight ratio of graphene oxide to mesoporous g- $\mathrm{C}_{3} \mathrm{~N}_{4}$ was controlled at $1.0 \mathrm{wt} \%$.

cWeight ratio of $\mathrm{K}$ to g- $\mathrm{C}_{3} \mathrm{~N}_{4}$ was $5 \%$.

d Molar ratio of $\mathrm{Ag}$ to $\mathrm{g}-\mathrm{C}_{3} \mathrm{~N}_{4}$ was $10 \%$.

e Mass ratio of $\mathrm{Bi}$ to $\mathrm{g}-\mathrm{C}_{3} \mathrm{~N}_{4}$ was $25 \%$.

higher and lower under visible-light irradiation, respectively, than those of reported photocatalytic materials based on modified g- $\mathrm{C}_{3} \mathrm{~N}_{4}$ [21], K-intercalated g- $\mathrm{C}_{3} \mathrm{~N}_{4}$ [22], Ag-doped g- $\mathrm{C}_{3} \mathrm{~N}_{4}$ [23], and even a Bi sphere/g- $\mathrm{C}_{3} \mathrm{~N}_{4}$ nanohybrid with $\mathrm{Bi}_{2} \mathrm{O}_{3}$ layers [19] (Table 1). This result suggests that a composite consisting of pure $\mathrm{Bi}$ metal hybridized with g- $\mathrm{C}_{3} \mathrm{~N}_{4}$ can far outperform those consisting of g- $_{3} \mathrm{~N}_{4}$ modified with noble metals, graphene materials, Bi metal with impurities in nitrate formation, displaying both high photo-oxidation ability and selectivity. Therefore, it is worth comprehensively investigating the Bi-CN composite system in terms of structure and physical merits.

The initial NO concentration in the feed gas was $600 \times 10^{-9}$ and the concentration of $\mathrm{NO}_{2}$ from the outlet was less than $50 \times$ $10^{-9}$ at more than 50\% NO conversion (Fig. 1(a) and (b)), indicating that $\mathrm{NO}_{2}$ was not the major product. This is because $\mathrm{NO}_{2}$ is not the final product of $\mathrm{NO}$ photo-oxidation; $\mathrm{NO}_{2}$ can further oxidize to $\mathrm{NO}_{3}{ }^{-}$over $\mathrm{g}-\mathrm{C}_{3} \mathrm{~N}_{4}$ [23]. However, quantitative detection of the NO oxidation intermediates adsorbed on the photocatalyst surface still remains a great challenge.

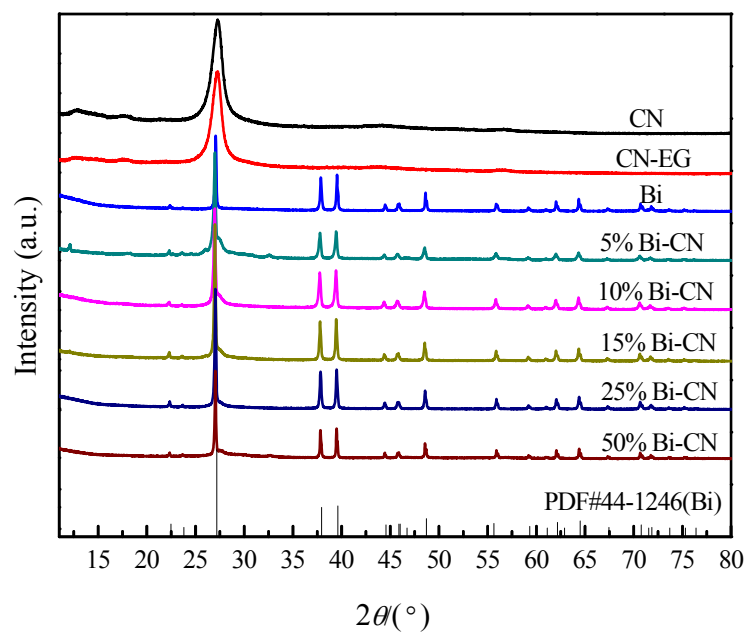

Fig. 2. XRD patterns of the photocatalytic materials.

\subsection{Photocatalyst structure and composition}

To ascertain whether or not Bi exists in the Bi-CN composites in its elemental form, XRD was carried out. Fig. 2 reveals that the pattern of $\mathrm{CN}-\mathrm{EG}$ is quite similar to that of pristine g- $\mathrm{C}_{3} \mathrm{~N}_{4}$. However, CN-EG showed a slightly broadened main peak centered at around $27.5^{\circ}$ compared with that of $g-\mathrm{C}_{3} \mathrm{~N}_{4}$, which may result from the decreased crystallite size following solvothermal treatment. The XRD patterns of the Bi-CN composites contained peaks consistent with the rhombohedral phase of Bi metal (JCPDS PDF card 44-1246), which confirmed the existence of Bi metal in the Bi-CN composites. No obvious diffraction peaks of $\mathrm{g}-\mathrm{C}_{3} \mathrm{~N}_{4}$ could be discerned because of the strong shadowing effect of the (012) peak of the Bi metal phase in the Bi-CN composites [19]. The presence of $\mathrm{g}-\mathrm{C}_{3} \mathrm{~N}_{4}$ in the Bi-CN composites was verified by FT-IR and XPS analyses.

The chemical bonding of the bare $\mathrm{g}-\mathrm{C}_{3} \mathrm{~N}_{4}, \mathrm{CN}-\mathrm{EG}, \mathrm{Bi}$, and Bi-CN composites was investigated by FT-IR spectroscopy. The solvothermally prepared CN-EG displayed FT-IR features akin to those of the pristine $\mathrm{g}-\mathrm{C}_{3} \mathrm{~N}_{4}$ (Fig. 3). Peaks observed at approximately 810 and $1242-1646 \mathrm{~cm}^{-1}$ were attributed to the characteristic breathing mode of a triazine ring system and typical stretching vibration modes of a g- $\mathrm{C}_{3} \mathrm{~N}_{4}$ heterocycle, respectively. Two strong bands centered at 1387 and $1645 \mathrm{~cm}^{-1}$ were consistent with the presence of Bi metal [24]. All of the main characteristic peaks of $\mathrm{g}-\mathrm{C}_{3} \mathrm{~N}_{4}$ and pure Bi were observed in the FT-IR spectra of all the Bi-CN composites, confirming the formation of composites between elemental Bi and $\mathrm{g}-\mathrm{C}_{3} \mathrm{~N}_{4}$ by solvothermal treatment. These Bi-CN composites may offer electron migration routes to improve photoinduced charge carrier separation and enhance photoactivity.

XPS analysis was conducted to investigate the surface chemical composition of the Bi-CN composites and the chemical state of $\mathrm{Bi}$ in them. The survey spectra in Fig. 4(a) reveal that $\mathrm{g}_{-} \mathrm{C}_{3} \mathrm{~N}_{4}$ and $\mathrm{CN}-\mathrm{EG}$ were composed of $\mathrm{C}, \mathrm{N}$, and a small amount of $\mathrm{O}$ originating from contamination from the atmosphere; no other peaks were observed. The spectrum for elemental $\mathrm{Bi}$ indicated the presence of $\mathrm{Bi}, \mathrm{C}$, and $\mathrm{O}$ species; the latter two may result from the easy oxidation of adventitious

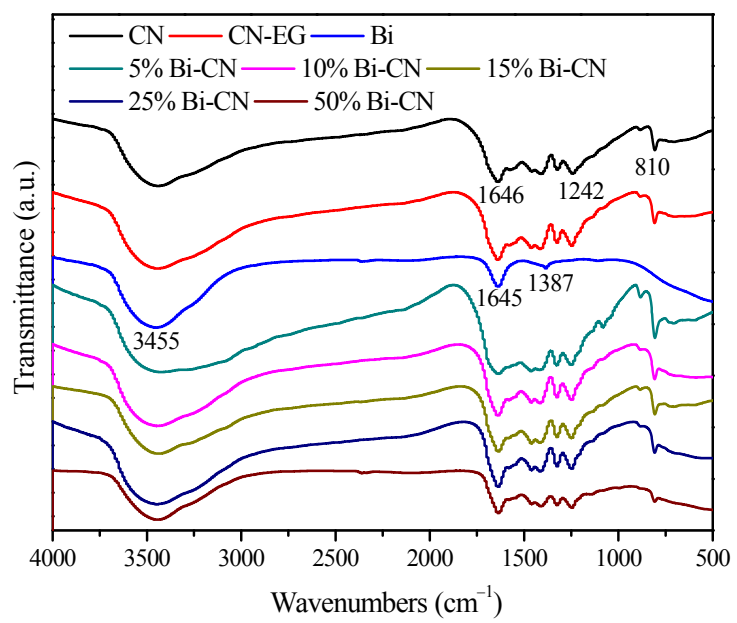

Fig. 3. FT-IR spectra of $\mathrm{g}-\mathrm{C}_{3} \mathrm{~N}_{4}(\mathrm{CN}), \mathrm{CN}-\mathrm{EG}, \mathrm{Bi}$, and $\mathrm{Bi}-\mathrm{CN}$ composites. 

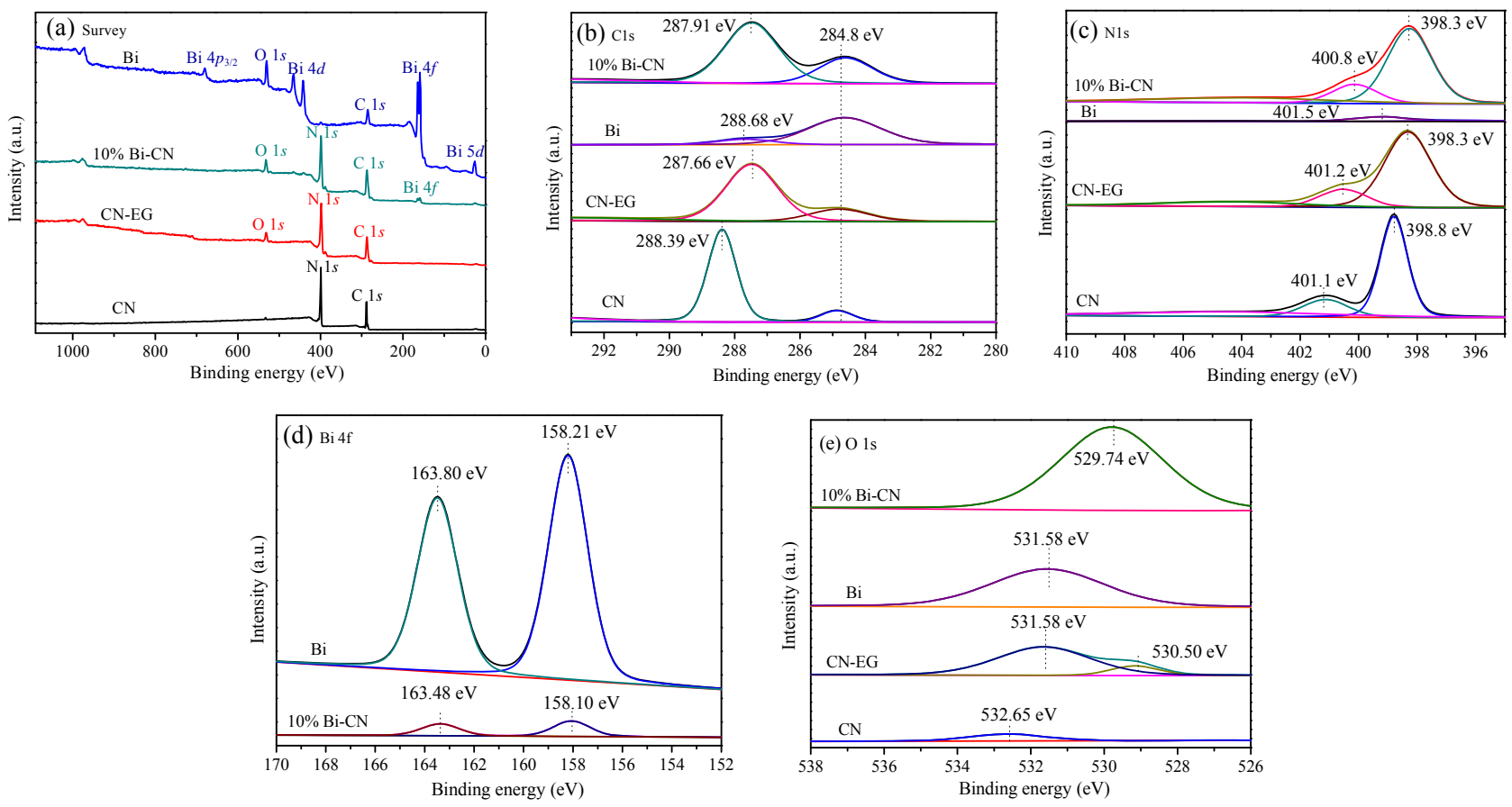

Fig. 4. XPS analysis of g- $\mathrm{C}_{3} \mathrm{~N}_{4}(\mathrm{CN}), \mathrm{CN}-\mathrm{EG}, \mathrm{Bi}$, and $10 \%$ Bi-CN composites. (a) Survey scan; (b) C 1s; (c) N 1s; (d) Bi 4f; (e) $01 s$.

carbon species in the air. The $10 \%$ Bi-CN composite contained $\mathrm{Bi}, \mathrm{C}, \mathrm{N}$, and a small amount of $\mathrm{O}$, which could originate from the surface absorption of $\mathrm{g}-\mathrm{C}_{3} \mathrm{~N}_{4}$. This spectrum indicates that the $\mathrm{Bi}$ in the $10 \% \mathrm{Bi}-\mathrm{CN}$ composite existed in its elemental form.

The high-resolution C $1 s$ spectra in Fig. 4(b) can be deconvoluted into two dominant peaks with binding energies of $\sim 284.8$ and $\sim 288.39 \mathrm{eV}$. The peak located at $284.8 \mathrm{eV}$ may be related to C-C and/or adventitious carbon, and that at 288.39 $\mathrm{eV}$ can be assigned to the $\mathrm{N}-\mathrm{C}-\mathrm{N}$ group of $\mathrm{g}-\mathrm{C}_{3} \mathrm{~N}_{4}$. The high-resolution $\mathrm{N} 1 \mathrm{~s}$ spectra in Fig. 4(c) could be fitted into two predominant peaks at 398.8 and $401.1 \mathrm{eV}$ and a weak peak at $404.5 \mathrm{eV}$, which are ascribed to $\mathrm{C}=\mathrm{N}-\mathrm{C}, \mathrm{C}-\mathrm{N}-\mathrm{H}$, and $\pi$-excitation, respectively. According to the $\mathrm{C} 1 s$ and $\mathrm{N} 1 s$ results, the composites contain no functional groups related to $\mathrm{Bi}-\mathrm{C}$ or $\mathrm{Bi}-\mathrm{N}$, indicating that elemental $\mathrm{Bi}$ was the major phase on the surface of the Bi-CN composites. The XPS data for Bi in Fig. 4(d) provide further evidence for the existence of elemental $\mathrm{Bi}$ in the Bi-CN composites. The Bi $4 f$ spectra could be fitted into a doublet corresponding to metallic Bi $4 f_{7 / 2}$ and metallic Bi $4 f_{5 / 2}$ at binding energies of 158.21 and $163.48 \mathrm{eV}$, respectively, which are almost equal to the standard binding energy of pure Bi metal. Furthermore, no other impurity phase was detected, such as the presence of $\mathrm{Bi}-0$ bonds. This revealed the presence of pure Bi metal in the $10 \% \mathrm{Bi}-\mathrm{CN}$ composite without any oxide impurities. Therefore, the $10 \% \mathrm{Bi}-\mathrm{CN}$ composite can take full advantage of the SPR effects derived from pure Bi metal to enhance its photocatalytic performance.

The $01 s$ spectrum (Fig. 4(e)) was fitted into one peak at a binding energy of $532.65 \mathrm{eV}$, which was ascribed to adsorbed $\mathrm{H}_{2} \mathrm{O}$. As reported previously, the introduction of amine groups into a carbon carrier can result in an increased percentage of zeroth-order metal that is resistant to re-oxidation during air contact [25]. In our Bi-CN composite system, the solvothermally prepared $\mathrm{g}-\mathrm{C}_{3} \mathrm{~N}_{4}$ has a high nitrogen content. These $\pi$-bonded planar $\mathrm{C}-\mathrm{N}-\mathrm{C}$ layers along with their incompletely condensed amino groups can stabilize highly dispersed $\mathrm{Bi}$ and prevent its oxidation. Additionally, the use of $\mathrm{NaBiO}_{3} \cdot 2 \mathrm{H}_{2} \mathrm{O}$ as a precursor avoids the oxidation of $\mathrm{Bi}$ metal during the composite preparation process.

\subsection{Optical properties and possible photocatalytic mechanism}

To explore the underlying photocatalytic mechanism of the composites, their optical properties were investigated by UV-vis DRS; the results are illustrated in Fig. 5. The absorption band edges of both g- $\mathrm{C}_{3} \mathrm{~N}_{4}$ and CN-EG appeared at $\lambda<465 \mathrm{~nm}$, which were attributed to the distinctive absorption of $g-\mathrm{C}_{3} \mathrm{~N}_{4}$ with a band-gap energy of ca. $2.7 \mathrm{eV}$. In contrast, the Bi-CN composites strongly absorbed light from the UV to the near-infrared range (200-800 nm) after the introduction of Bi. The absorption intensity of the Bi-CN composites gradually strengthened with increasing Bi content, which in turn increased the utilized efficiency of solar light, and thus improved photocatalytic oxidation capacity. The strong light absorption of the Bi-CN composites originated from the characteristic SPR effect of Bi metal. Dong et al. [19] reported that pure Bi nanospheres with diameters of 150-200 nm displayed a SPR peak centered at approximately $500 \mathrm{~nm}$. However, in our case, no peaks characteristic of the SPR of Bi metal were observed in the range of 200-800 nm. Recently, Toudert et al. [26] found that the absorption properties of spheroidal Bi nanoparticles were sensitive to its size, shape, and organization, and also explored the tunability of the transverse resonance of Bi nanoparticles 

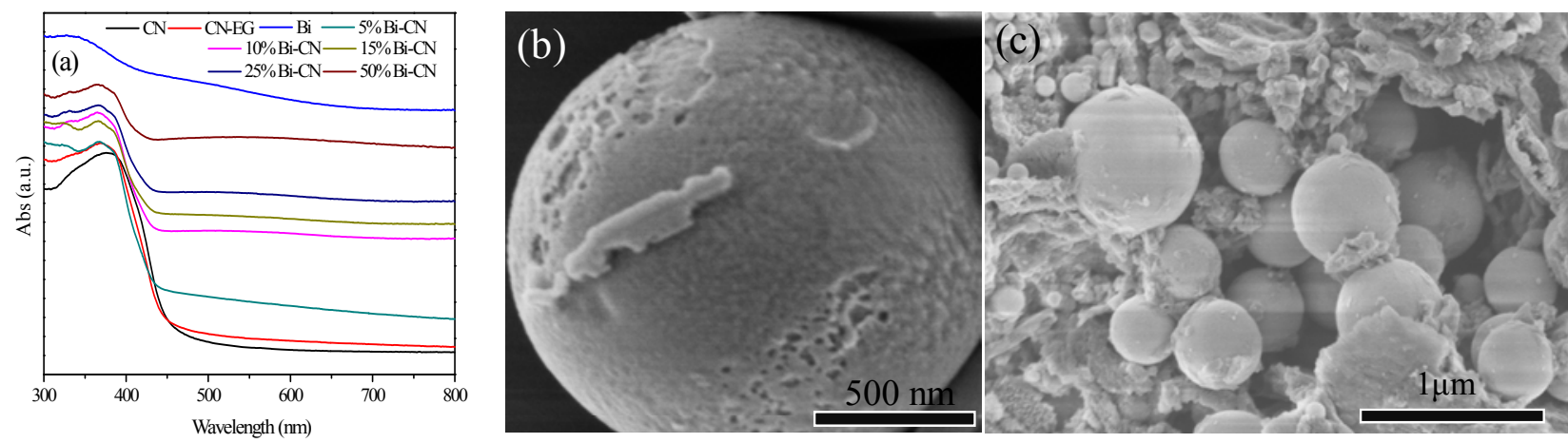

Fig. 5. UV-vis DRS of g- $\mathrm{C}_{3} \mathrm{~N}_{4}$ (CN), CN-EG, Bi, and Bi-CN composites (a). SEM images of $\mathrm{Bi}$ (b) and $10 \% \mathrm{Bi}-\mathrm{CN}$ composite (c).

by controlling their size and shape. They predicted that "large" spheroidal Bi nanoparticles should be excellent candidates to obtain well-defined resonances that could be tuned from the near-UV to the near-infrared region. Fig. 5(b) shows that the as-prepared $\mathrm{Bi}$ metal particles were sphere-like with a diameter of around $1 \mu \mathrm{m}$. It is therefore reasonable to consider that high tunability of SPR from the UV through to the near-infrared region (beyond $800 \mathrm{~nm}$ ) can be achieved by incorporation of $\mathrm{Bi}$ metal particles with a large size. The uniform dispersion of $\mathrm{Bi}$ spheres with average diameters of approximately $300 \mathrm{~nm}$ was well-coupled with the thick g- $\mathrm{C}_{3} \mathrm{~N}_{4}$ layers (Fig. 5(c)). The decreased size of the Bi spheres in the Bi-CN composite compared with that of the Bi particles alone can be ascribed to a grain boundary size effect of $\mathrm{g}-\mathrm{C}_{3} \mathrm{~N}_{4}$ during the solvothermal thermal process. Because of the decreased size of $\mathrm{Bi}$ spheres in the composites, the SPR peak of Bi metal was not detected in Fig. 5(a). Gérard et al. [27] reported that the experimental scattering spectra of individual $\mathrm{Al}$ nanodisks with diameters varying from 70 to $180 \mathrm{~nm}$ displayed a bathochromic shift from around 300 to $550 \mathrm{~nm}$ as diameter increased. This provides evidence that the Bi-CN composites display an SPR peak (typically longer than $800 \mathrm{~nm}$ ) originating from large Bi metal particles.

Strong visible-light absorption is only one of the important factors to realize a high-efficiency photocatalytic composite. The effective separation of photogenerated electron-hole pairs

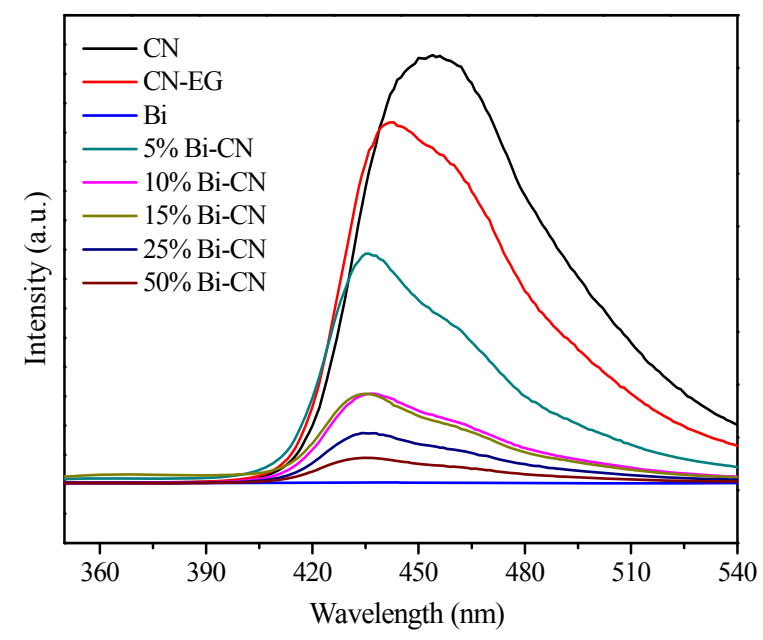

Fig. 6. PL spectra of $g-\mathrm{C}_{3} \mathrm{~N}_{4}(\mathrm{CN}), \mathrm{CN}-\mathrm{EG}, \mathrm{Bi}$, and $\mathrm{Bi}-\mathrm{CN}$ composites. in a photocatalytic composite is needed for efficient photo-oxidation of NO. Therefore, PL spectra of the composites were obtained, as shown in Fig. 6. After the addition of Bi metal, considerable PL quenching was observed for the Bi-CN composites. The obvious quenching of the PL emission peak intensity of the Bi-CN composites was attributed to unidirectional electron migration from the conduction band (CB) of g- $\mathrm{C}_{3} \mathrm{~N}_{4}$ to $\mathrm{Bi}$ metal because of the Mott-Schottky effect of Bi metal [19]. Therefore, the Bi dispersed on the surface of $\mathrm{g}-\mathrm{C}_{3} \mathrm{~N}_{4}$ could effectively hinder electron-hole recombination, which is very promising for achieving photo-oxidation with satisfying activity. Aside from the different emission intensities of these photocatalysts, there are subtle yet revealing differences between these spectra. Compared with the peak for $\mathrm{g}-\mathrm{C}_{3} \mathrm{~N}_{4}$, those of both CN-EG and Bi-CN composites show a hypsochromic shift, which can be attributed to the quantum sizes effects originating from solvothermal treatment decreasing the size of $\mathrm{g}-\mathrm{C}_{3} \mathrm{~N}_{4}$ layers, consistent with previous results [19].

Specific surface area is another important parameter of photocatalysts. The specific surface area of each photocatalyst was determined by $\mathrm{N}_{2}$ adsorption-desorption measurements to ascertain its possible contribution to photocatalytic reactions. Fig. 7(a) reveals that the isotherms were typical of type IV with a hysteresis loop observed at $P / P_{0}=0.5-1.0$. This suggests both g- $\mathrm{C}_{3} \mathrm{~N}_{4}$ and the composites are mesoporous, with no evident plugging or change of the $\mathrm{g}-\mathrm{C}_{3} \mathrm{~N}_{4}$ structure after the inclusion of Bi metal (Table 1 and Fig. 7(b)). The specific surface area of CN-EG is $53 \mathrm{~m}^{2} \mathrm{~g}^{-1}$, which is about six times higher than that of pristine $\mathrm{g}-\mathrm{C}_{3} \mathrm{~N}_{4}\left(9 \mathrm{~m}^{2} \mathrm{~g}^{-1}\right)$. The specific surface area of $10 \%$ Bi-CN is $42 \mathrm{~m}^{2} \mathrm{~g}^{-1}$, slightly lower that of CN-EG. Additionally, the pore size distributions in Fig. 7(b) reveal that the pores in g- $\mathrm{C}_{3} \mathrm{~N}_{4}$ and $10 \%$ Bi-CN are mainly distributed in the range of 1.8-6.8 nm, corresponding to mesoporous structure. Upon increasing the Bi content to $15 \%$, the specific surface area and pore size distribution of the composite were almost unchanged but its photocatalytic activity deteriorated compared with that of the $10 \% \mathrm{Bi}-\mathrm{CN}$ composite. Consequently, this experiment ruled out the contribution of surface area to the photocatalytic activity of the composites.

From the perspective of maximizing the visible-light photocatalytic performance of the composites, we chose to elucidate a possible photocatalytic mechanism of the $10 \% \mathrm{Bi}-\mathrm{CN}$ composite. On the basis of the results described above, we propose the 

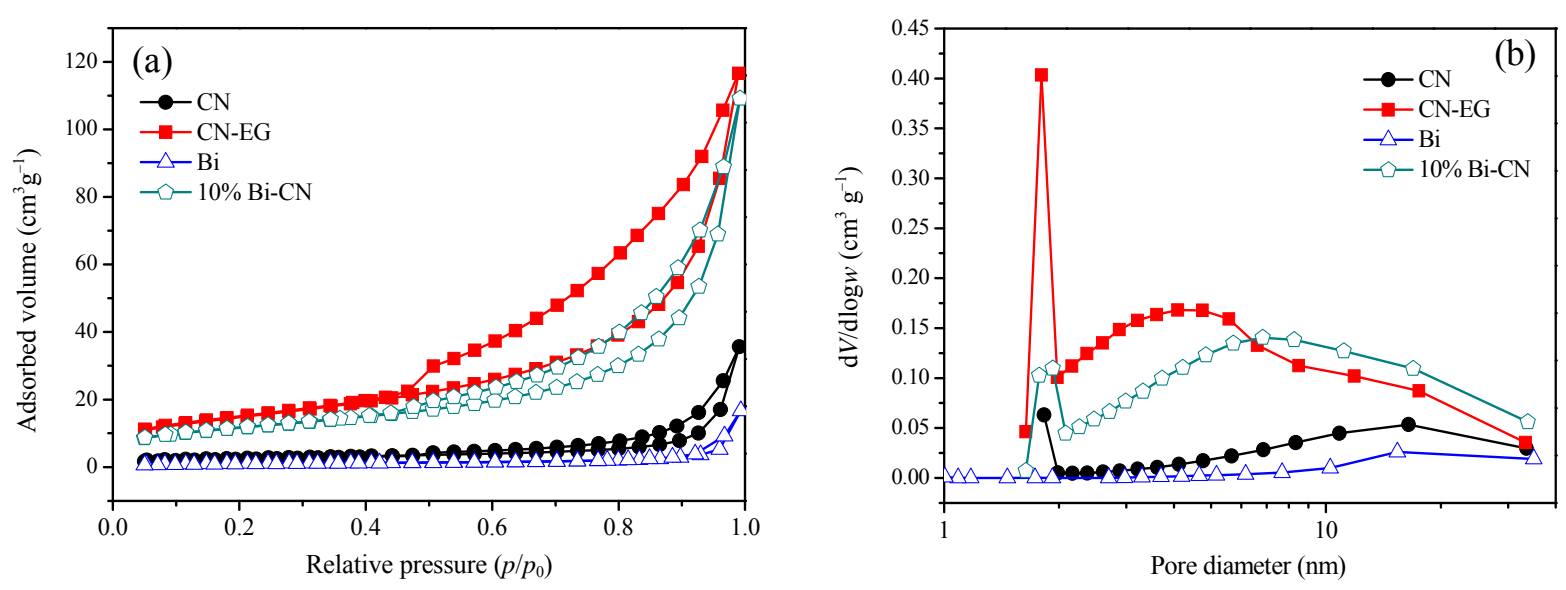

Fig. 7. Nitrogen adsorption-desorption isotherms (a), and the corresponding pore size distributions of the photocatalysts (b).

following mechanism, as shown in Scheme 1. The appearance of the $10 \%$ Bi-CN composite with Bi spheres embedded in a g- $\mathrm{C}_{3} \mathrm{~N}_{4}$ layer resembles pomegranate. The UV-vis DRS results indicated that the introduction of metallic Bi greatly enhanced the photoabsorption performance of the $10 \% \mathrm{Bi}-\mathrm{CN}$ composite because of the SPR effect of Bi metal. Meanwhile, the PL experiment revealed that the addition of $\mathrm{Bi}$ metal to g- $\mathrm{C}_{3} \mathrm{~N}_{4}$ promoted the effective separation of photoexcited charge carriers because Bi metal in the composite formed a Schottky barrier at the metal/g- $\mathrm{C}_{3} \mathrm{~N}_{4}$ interface [19]. These two factors are the basis of the high photoactivity of the $10 \% \mathrm{Bi}-\mathrm{CN}$ composite. Furthermore, the favorable coupling effect of Bi metal with $\mathrm{g}-\mathrm{C}_{3} \mathrm{~N}_{4}$ also plays an important role in its high photoactivity based on the results of photocatalytic testing. As illustrated in Scheme 1, the photogenerated electrons in the $\mathrm{CB}$ of $\mathrm{g}-\mathrm{C}_{3} \mathrm{~N}_{4}$ would transfer to metallic Bi because the $\mathrm{CB}$ of $\mathrm{CN}$ is more negative than the Fermi level of metallic Bi. Simultaneously, the holes accumulate in the VB of g- $\mathrm{C}_{3} \mathrm{~N}_{4}$, which possesses sufficient oxidizing ability to degrade NO. This type of charge transmission greatly improved the separation of charge carriers and enabled the photogenerated electrons and holes to remain on the surface of metallic $\mathrm{Bi}$ and $\mathrm{VB}$ of $\mathrm{g}-\mathrm{C}_{3} \mathrm{~N}_{4}$, respectively, allowing them to react with air and water, and thus produce active species to

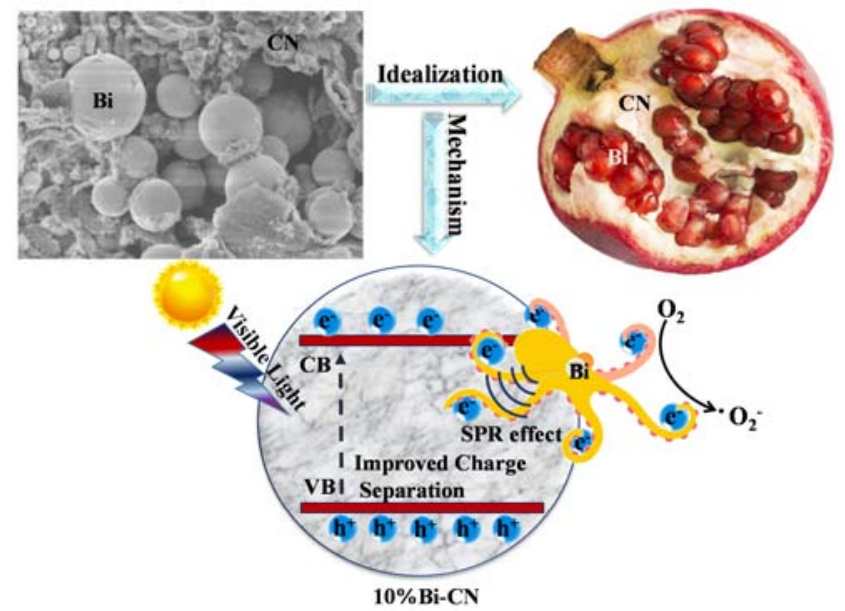

Scheme1. Proposed photocatalytic oxidation NO mechanism for the $10 \%$ Bi-CN composite. realize photo-oxidation of NO.

\subsection{Photocatalyst stability}

It is known that photocorrosion might occur on the photocatalyst surface during photocatalytic reaction. To test the stability of the catalysts in NO photocatalytic oxidation, we reused the $10 \%$ Bi-CN photocatalyst five times. Fig. 8 shows that the activity of the photocatalyst after five consecutive cycles was nearly the same as that of the fresh one. The high stability of the photocatalyst was attributed to the strong interaction between pure Bi metal and g- $\mathrm{C}_{3} \mathrm{~N}_{4}$, and indicates that composites consisting of $\mathrm{g}-\mathrm{C}_{3} \mathrm{~N}_{4}$ modified with pure Bi metal are promising for use in practical applications like air purification.

\section{Conclusions}

An in situ solvothermal treatment strategy to prepare Bi-CN composites with a pomegranate-like structure was developed. Pure $\mathrm{Bi}$ metal obtained using $\mathrm{NaBiO}_{3} \cdot 2 \mathrm{H}_{2} \mathrm{O}$ as the precursor was successfully used to modify $\mathrm{g}-\mathrm{C}_{3} \mathrm{~N}_{4}$. Embedding pure spherical Bi metal particles in $\mathrm{g}-\mathrm{C}_{3} \mathrm{~N}_{4}$ layers had two main advantages. Firstly, because of the unique chemical and physical properties of pure Bi metal, together with the efficient function

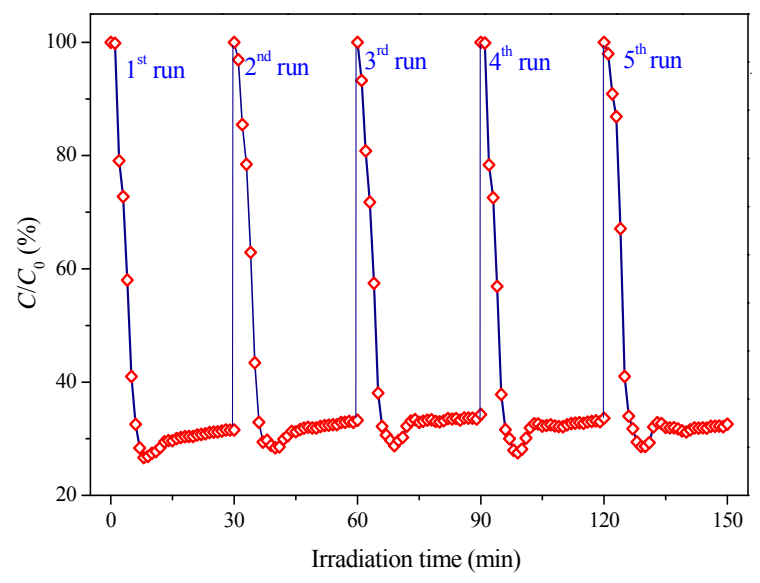

Fig. 8. Photocatalytic oxidation curves of NO reusing $10 \% \mathrm{Bi}-\mathrm{CN}$. 


\section{Graphical Abstract}

Chin. J. Catal., 2017, 38: 321-329 doi: 10.1016/S1872-2067(16)62573-1

\section{Enhanced visible-light photo-oxidation of nitric oxide using bismuth-coupled graphitic carbon nitride composite} heterostructures

Yuhan Li, Kangle Lv*, Wing-Kei Ho*, Zaiwang Zhao, Yu Huang

The Education University of Hong Kong; Institute of Earth Environment, Chinese Academy of Sciences; South-Central University for Nationalities

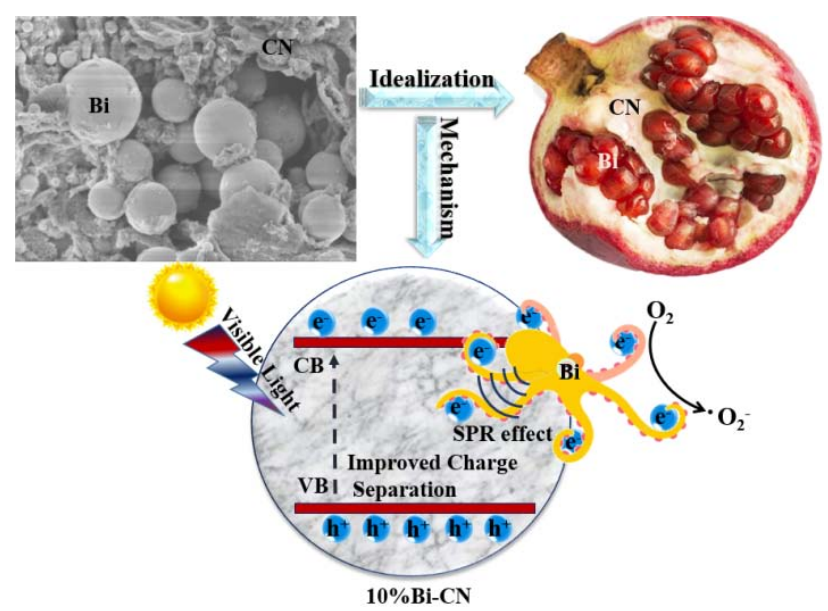

The introduction of bismuth metal to graphitic carbon nitride resulted in composites that displayed improved light absorption over the entire visible range, effective separation of photogenerated electron-hole pairs, and high visible-light photocatalytic activity in oxidation of NO.

of the cocatalyst, the resulting Bi-CN composites displayed strongly absorption light over the entire spectral range. Secondly, the favorable match of Bi with $\mathrm{g}-\mathrm{C}_{3} \mathrm{~N}_{4}$ resulted in beneficial Mott-Schottky effects at their interfaces, and thus a fast separation rate of photogenerated electrons and holes. The high stability of the obtained Bi-CN composites makes them promising for use in practical applications such as air purification.

\section{Acknowledgment}

This work was supported by the National Program on Key Basic Research Project (2016YFA0203000), the Early Career Scheme (ECS 809813) from the Research Grant Council, Hong Kong SAR Government, and the Croucher Foundation Visitorship for PRC Scholars 2015/16 at The Education University of Hong Kong. This work was also supported by the National Natural Science Foundation of China (51672312, 21373275) and the Program for New Century Excellent Talents in University (NCET-12-0668).

\section{References}

[1] Y. H. Li, L. P. Yang, G. H. Dong, W. K. Ho, Molecules, 2016, 21, $36-46$.

[2] Q. Zhang, Y. Zhou, F. Wang, F. Dong, W. Li, H. M. Li, G. R. Patzke, J. Mater. Chem. A, 2014, 2, 11065-11072.

[3] P. Wan, B. B. Huang, Y. Dai, M. H. Whangbo, Phys. Chem. Chem.
Phys., 2012, 14, 9813-9825.

[4] M. A. El-Sayed, Acc. Chem. Res., 2001, 34, 257-264.

[5] N. Pradhan, A. Pal, T. Pal, Langmuir, 2001, 17, 1800-1802.

[6] X. W. Liu, H. Q. Cao, J. F. Yin, Nano Res., 2011, 4, 470-482.

[7] S. X. Weng, B. B. Chen, L. Y. Xie, Z. Y. Zheng, P. Liu, J. Mater. Chem. A, 2013, 1, 3068-3075.

[8] Y. Yu, C. Y. Cao, H. Liu, P. Li, F. F. Wei, Y. Jiang, W. G. Song, J. Mater. Chem. A, 2014, 2, 1677-1681.

[9] F. Dong, Q. Y. Li, Y. J. Sun, W. K. Ho, ACS Catal., 2014, 4, 4341-4350.

[10] Z. Wang, C. L. Jiang, R. Huang, H. Peng, X. D. Tang, J. Phys. Chem. C, 2014, 118, 1155-1160.

[11] F. Dong, T. Xiong, Y. J. Sun, Z. W. Zhao, Y. Zhou, X. Feng, Z. B. Wu, Chem. Commun., 2014, 50, 10386-10389.

[12] J. Zhang, T. He, B. Liu, L. Liu, Z. L. Zhao, D. Q. Hu, X. H. Ju, G. T. Wu, P. Chen, Chin. J. Catal., 2013, 34, 1303-1311.

[13] Y. Shiraishi, S. Kanazawa, Y. Sugano, D. Tsukamoto, H. Sakamoto, S. Ichikawa, T. Hirai, ACS Catal., 2014, 4, 774-780.

[14] P. Wang, S. H. Sun, X. Y. Zhang, X. Ge, W. Lü, RSC Adv., 2016, 6, 33589-33598.

[15] X. C. Wang, K. Maeda, X. F. Chen, K. Takanabe, K. Domen, Y. D. Hou, X. Z. Fu, M. Antonietti, J. Am. Chem. Soc., 2009, 131, 1680-1681.

[16] Y. J. Cui, Chin. J. Catal., 2015, 36, 372-379.

[17] F. Dong, Z. L. Ni, P. D. Li, Z. B. Wu, New J. Chem., 2015, 39, 4737-4744.

[18] B. Yuan, J. X. Wei, T. J. Hu, H. B. Yao, Z. H. Jiang, Z. W. Fang, Z.Y. Chu, Chin. J. Catal., 2015, 36, 1009-1016.

[19] F. Dong, Z. W. Zhao, Y. J. Sun, Y. X. Zhang, S. Yan, Z. B. Wu, Environ. Sci. Technol., 2015, 49, 12432-12440.

[20] Q. L. Gu, K. J. Zhu, N. S. Zhang, Q. M. Sun, P. C. Liu, J. S. Liu, J. Wang, Z. S. Li, J. Phys. Chem. C, 2015, 119, 25956-25964. 
[21] Y. H. Li, Y. J. Sun, F. Dong, W. K. Ho, J. Colloid Interface Sci., 2014, 436, 29-36.

[22] T. Xiong, W. L. Cen, Y. X. Zhang, F. Dong, ACS Catal, 2016, 6, 2462-2472.

[23] Y. J. Sun, T. Xiong, Z. L. Ni, J. Liu, F. Dong, W. Zhang, W. K. Ho, Appl. Surf. Sci., 2015, 358: 356-362.

[24] E. R. Swy, A. S. Schwartz-Duval, D. D. Shuboni, M. T. Latourette, C.
L. Mallet, M. Parys, D. P. Cormode, E. M. Shapiro, Nanoscale, 2014, 6: 13104-13112.

[25] Y. Wang, J. Yao, H. R. Li, D. S. Su, M. Antonient, J. Am. Chem. Soc, 2011, 133: 2362-2365.

[26] J. Toudert, R. Serna, M. J. de Castro, J. Phys. Chem. C, 2012, 116: 20530-20539.

[27] D. Gérard, S. K. Gray, J. Phys. D: Appl. Phys, 2015, 48: 1-14.

\title{
石榴状单质铋(Bi)球与 $g-\mathrm{C}_{3} \mathrm{~N}_{4}$ 复合材料表现出超强可见光氧化 $\mathrm{NO}$ 性能
}

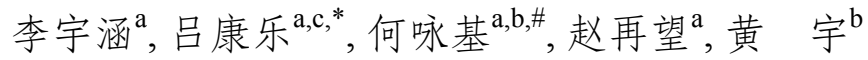 \\ a香港教育大学科学与环境系, 香港 \\ $\mathrm{b}$ 中国科学院地球环境研究所气溶胶化学与物理重点实验室, 陕西西安710061 \\ ${ }^{\mathrm{c}}$ 中南民族大学资源与环境学院, 湖北武汉 430074
}

摘要: 采用一种原位合成工艺制备了具有类石榴结构的金属铋(Bi)单质修饰的 $\mathrm{g}-\mathrm{C}_{3} \mathrm{~N}_{4}$ 复合材料 $(\mathrm{Bi}-\mathrm{CN})$, 并用于可见光氧化 $\mathrm{NO}$ 反应中. 金属 $\mathrm{Bi}$ 单质镶嵌在 $\mathrm{CN}$ 层间形成的复合物, 由于金属 $\mathrm{Bi}$ 单质显著的表面等离子体共振(SPR)作用可将光吸收范 围由紫外光延展至近红外, 极大地提高了复合物的光吸收. 此外, 由于Bi单质存在于复合物界面可产生内建莫特-肖特基效 应, 从而加快光生载流子的分离与转移. 由此, Bi-CN复合物光催化剂展现出超强的光催化去除 $\mathrm{NO}$ 性能. 我们提出了类石 榴结构的形成以及相应的Bi-CN复合物光催化活性的提高机理. 这不仅为高效的金属铋单质改性的 $\mathrm{g}-\mathrm{C}_{3} \mathrm{~N}_{4}$ 基光催化剂提 供了一种新的设计方案, 也对 $\mathrm{g}-\mathrm{C}_{3} \mathrm{~N}_{4}$ 基光催化的机制理解提出了新的见解.

通过 $X$ 射线衍射、红外光谱和 $X$ 射线光电子能谱结果发现 $\mathrm{Bi}$ 是以金属单质的形式存在于Bi-CN复合物中, 这得益于我们 采用了二水合铋酸钠 $\left(\mathrm{NaBiO}_{3} \cdot 2 \mathrm{H}_{2} \mathrm{O}\right)$ 作为铋前驱体, 从而成功避免了氧化态铋的形成. $\mathrm{Bi}-\mathrm{CN}$ 复合物中金属铋单质的存在 有诸多优点. 首先, 金属铋单质具有显著的表面SPR效应, 它的引入可大大提高复合物的光吸收能力和太阳光利用率. 有 研究表明, 直径为 $150-200 \mathrm{~nm}$ 的铋球能够在紫外-可见漫反射图谱(UV-vis)在 $\lambda=500 \mathrm{~nm}$ 处呈现出典型的SPR 峰, 但本样品 在 $\lambda=200-800 \mathrm{~nm}$ 区间内并未发现该SPR峰. 由于铋单质的共振受限于其尺寸大小、颗粒形状和构造环境. 本文中球形铋 单质的直径约为 $1 \mu \mathrm{m}$, 其可能发生共振效应的峰位置应超过 $800 \mathrm{~nm}$, 因此未发现相应的SPR峰. 其次, 金属铋单质分散在 $\mathrm{CN}$ 层表面上构建的肖特基垫垒能够高效地阻止光生电子与空穴的复合, 促进了光生载流子的分离与转移, 从而提高光氧 化 NO进程. 再者, 金属铋单质的介入成功构造了 $\mathrm{Bi}-\mathrm{CN}$ 异质结, 在可见光照射下 $\mathrm{NO}$ 氧化反应中, Bi-CN复合物活性显著高 于 $\mathrm{CN}(22.2 \%) 、 \mathrm{CN}-\mathrm{EG}(36.4 \%)$ 和 $\mathrm{Bi}(14.1 \%)$, 其中以 $10 \% \mathrm{Bi}-\mathrm{CN}$ 活性最佳, $\mathrm{NO}$ 去除率到 $70.4 \%$, 远远超过 $\mathrm{K}$ 插层的 $\mathrm{g}-\mathrm{C}_{3} \mathrm{~N}_{4} 、 \mathrm{Ag}$ 掺杂的 $\mathrm{g}-\mathrm{C}_{3} \mathrm{~N}_{4}$ 和氧化石墨烯修饰的 $\mathrm{g}-\mathrm{C}_{3} \mathrm{~N}_{4}$.

当复合物中金属铋单质含量超过 $10 \%$ 时, 其活性明显下降. 这是因为大量的金属铋单质积聚在Bi-CN复合物表面上而 造成物理堵塞, 妨碍了 $\mathrm{CN}$ 吸收可见光, 从而降低了其可见光吸收能力; 同时导致只会吸收更多的紫外光 $(\lambda<280 \mathrm{~nm})$ 而不是 可见光, 因而其可见光催化氧化NO能力下降.

关键词: 金属铋; 表面等离子体共振; 光氧化; 一氧化氮; 可见光; 石墨型碳化氮

收稿日期: 2016-08-30. 接受日期: 2016-10-05. 出版日期: 2017-02-05.

*通讯联系人.电话: (027)67841369; 传真: (027)67843918; 电子信箱: lvkangle@mail.scuec.edu.cn

\#通讯联系人. 电话: (+852)29488255; 传真: (+852)29487726; 电子信箱: keithho@eduhk.hk

基金来源: 国家重点基础研究发展规划(2016YFA0203000), 香港特别行政区政府研究资助局杰出青年学者计划(ECS 809813), 香 港教育大学装槎中国访问学者计划(2015-2016), 国家自然科学基金（51672312和21373275）以及教育部 “新世纪优秀人才支持计 划” (NCET-12-0668).

本文的英文电子版由Elsevier出版社在ScienceDirect上出版(http://www.sciencedirect.com/science/journal/18722067). 